\title{
Rubiaceae Juss. da Reserva Florestal Mata do Paraíso, Viçosa, MG, Brasil
}

\author{
Zefa Valdivina Pereira $^{1,2}$, Rita Maria de Carvalho-Okano ${ }^{1}$ e Flávia Cristina Pinto Garcia ${ }^{1}$
}

Recebido em 16/02/2005. Aceito em 11/08/2005.

\begin{abstract}
RESUMO - (Rubiaceae Juss. da Reserva Florestal Mata do Paraíso, Viçosa, MG, Brasil). Este trabalho consiste no levantamento florístico e estudo taxonômico da família Rubiaceae, da Reserva Florestal Mata do Paraíso, Viçosa, MG. Foram registrados para a Reserva 14 gêneros compreendendo 30 espécies. Destas, 19 apresentaram hábito arbustivo e 11 são herbáceos. Os gêneros com maior número de espécies foram Psychotria (10 espécies), Borreria (quatro), Coccocypselum (três) e Coussarea e Palicourea (duas). Bathysa, Chiococca, Coutarea, Diodia, Faramea, Galium, Mitracarpus, Richardia e Rudgea apresentaram uma única espécie cada. São fornecidas neste trabalho chaves analíticas, descrições, ilustrações, comentários taxonômicos e distribuição geográfica para cada espécie.
\end{abstract}

Palavras-chave: Rubiaceae, taxonomia, florística, floresta semidecidual

\begin{abstract}
Rubiaceae Juss. from Mata do Paraíso Forest Reserve, Viçosa, Minas Gerais State, Brazil). This work consists of a floristic survey and a taxonomical study of the Rubiaceae at the Mata do Paraíso Forest Reserve in Viçosa, Minas Gerais State, Brazil. Fourteen genera comprising thirty species were found in the Reserve. From this total, nineteen were shrubs and eleven were herbs. The genera with larger species numbers were Psychotria (10), Borreria (four), Coccocypselum (three), and Coussarea and Palicourea (two). Bathysa, Chiococca, Coutarea, Diodia, Faramea, Galium, Mitracarpus, Richardia and Rudgea presented one species. Analytic key, descriptions, illustrations, taxonomical comments and geographic distribution of each species were also presented in this paper.
\end{abstract}

Key words: Rubiaceae, taxonomy, floristic, semideciduous forest

\section{Introdução}

Rubiaceae inclui aproximadamente 637 gêneros e cerca de 10.700 espécies (Robbrecht 1988), distribuídas principalmente nas regiões tropicais e subtropicais, atingindo, porém, as regiões temperadas e frias da Europa e norte do Canadá (Judd et al. 1999). De acordo com a classificação de Robbrecht (1988), está dividida em quatro subfamílias, as quais incluem 39 tribos. No Brasil, está representada por 18 tribos, 101 gêneros e 1.010 espécies, distribuídas por diversas formações vegetacionais e apresentando grande ocorrência na Mata Atlântica (Barroso et al. 1991).

No Brasil, os trabalhos pioneiros sobre a taxonomia das Rubiaceae foram os de Müller (1881) e Schumann (1889), publicados na Flora Brasiliensis, nos quais foram descritas 1.002 espécies distribuídas em 99 gêneros e seis tribos. Embora esses trabalhos constituam no Brasil a base para qualquer estudo taxonômico do grupo, alguns estudos apontaram a necessidade de atualização, tanto da interpretação morfológica de caracteres, como da reavaliação taxonômica. Dentre os trabalhos de floras locais para a família destacam-se os de: Krause \& Hoehne (1922), Rambo (1962), Smith \& Downs (1956), Porto et al. (1977), Dillenburg \& Porto (1985), Jung-Mendaçolli (1994), Gomes (1996) e Jung-Mendaçolli (1999). Quanto às revisões de gêneros, destacam-se aos trabalhos de: Miotto (1975), Macias (dados não publicados), Germano Filho (1999), Costa \& Mamede (2002) e Gomes (2003).

Dada a riqueza de espécies desta família e a carência de informações relativas à flora da Reserva Florestal Mata do Paraíso, este trabalho teve como objetivos reconhecer os gêneros e as espécies de Rubiaceae ali ocorrentes, ampliando assim o conhecimento sobre sua distribuição geográfica; fornecer descrições, ilustrações, comentários e chave para a identificação dos táxons.

\footnotetext{
1 Universidade Federal de Viçosa, Departamento de Biologia Vegetal, CEP 36570-000, Viçosa, MG, Brasil

2 Autor para correspondência: zefap@bol.com.br
} 


\section{Material e métodos}

A Reserva Florestal Mata do Paraíso (RFMP) situa-se no Município de Viçosa, nas coordenadas 20³8'07" e 4251'31'W, abrangendo uma área de 194,36ha, com altitude média de $690 \mathrm{~m}$. A precipitação média anual, nos últimos trinta anos, foi $1.221 \mathrm{~mm}$, com temperatura média oscilando entre 19 e $22^{\circ} \mathrm{C}$. O clima, segundo Köppen, é do tipo Cwa, mesotérmico úmido com verões quentes e chuvosos e invernos frios e secos (Vianello \& Alvez 1991). A vegetação natural da Reserva faz parte do domínio da Floresta Atlântica (Rizzini 1992) e, de acordo com a classificação de Veloso et al. (1991), trata-se de um fragmento de Floresta Estacional Semidecidual Submontana.

Foram realizadas excursões quinzenais, no período de julho/2001 a setembro/2002, para coleta de material fértil de representantes de Rubiaceae. Os materiais foram coletados ao longo da trilha principal, adentrando cerca de $20 \mathrm{~m}$ para ambos os lados, da trilha do aceiro e de trilhas pré-existentes no interior da reserva, além de caminhadas, sem orientação pré-estabelecida.

O material botânico foi herborizado, identificado mediante literatura especializada e comparações com o acervo do Herbário do Departamento de Biologia Vegetal da Universidade Federal de Viçosa VIC, do Jardim Botânico do Rio de Janeiro (RB), do
Departamento de Botânica da Universidade Federal de Minas Gerais, Belo Horizonte (BHCB), e do Departamento de Botânica da Universidade Estadual de Campinas (UEC). O material coletado foi depositado no Herbário VIC. As siglas dos herbários estão de acordo com Holmgren et al. (1990).

A chave para identificação das espécies e as descrições foram baseadas nas variações morfológicas apresentadas pelos espécimes coletados na área. A largura da lâmina foliar foi medida na sua maior extensão. Para a corola, as medidas foram feitas em todo o seu comprimento incluindo os lobos. Para as espécies distílicas registrou-se a faixa de variação entre as medidas das duas formas florais exceto para as espécies de Coccocypselum e Psychotria hygrophiloides Benth., nas quais só foi encontrada uma das formas florais.

\section{Resultados e discussão}

Na RFMP, foram reconhecidos 30 táxons de Rubiaceae distribuídos em 14 gêneros. Destas, 19 apresentaram hábito arbustivo ou arbóreo e 11 herbáceo. Os gêneros mais representativos são Psychotria com 10 espécies, Borreria com quatro, Coccocypselum com três, Palicourea e Coussarea com duas, e os demais gêneros com uma única espécie.

Chave para identificação das espécies de Rubiaceae da Reserva Florestal Mata do Paraíso Viçosa, MG

1. Árvores ou arbustos

2. Flores tetrâmeras

3. Ovário bilocular; fruto cápsula septicida

1. Bathysa nicholsonii

3. Ovário unilocular; fruto bacaceo

4. Estípulas livres, ápice agudo ou obtuso; semente presa verticalmente na base

5. Folhas opostas; inflorescências em cimeiras trifloras; corola com mais de $15 \mathrm{~mm}$; pericarpo muricado 10. Coussarea triflora

5. Folhas verticiladas; inflorescências em cimeiras paniculiformes; corola com menos de $15 \mathrm{~mm}$; pericarpo liso 11. Coussarea verticillata

4. Estípulas conadas, ápice aristado; semente presa horizontalmente na base

14. Faramea multiflora

2. Flores pentâmeras ou hexâmeras

6. Árvores; flores hexâmeras; fruto cápsula loculicida 12. Coutarea hexandra

6. Arbustos; flores pentâmeras; fruto drupáceo

7. Estípulas inteiras com segmentos subulados agrupados próximo do ápice ....30. Rudgea lanceolata

7. Estípulas inteiras ou bilobadas sem segmentos subulados

8. Flores homostílicas; antera basifixa; semente lisa 6. Chiococca alba

8. Flores distílicas; antera dorsifixa; semente costada 
9. Corola gibosa na base; anel de tricomas internamente próximo à base; presença de linha de articulação entre o pedicelo e o hipanto

10. Arbustos escandentes; pecíolo 1,5-2,3 cm compr.; cimeiras, paniculiformes, axilares, pedúnculo $11-15 \mathrm{~cm}$ compr. 17. Palicourea longepedunculata

10. Arbustos eretos; pecíolo 3-6 mm compr.; cimeiras corimbiformes, terminais, pedúnculo 3-4 cm compr. 18. Palicourea marcgravii

9. Corola reta na base; anel de tricomas internamente na região mediana ou acima desta; sem linha de articulação entre o pedicelo e o hipanto

11. Lâminas foliares estreitas, relação comprimento/largura maior que 3/1

12. Nervuras secundárias com menos de 10 pares, não paralelas, oblíquas à nervura primária, margem foliar ondulada 27. Psychotria subsphatulata

12. Nervuras secundárias com mais de 20 pares, paralelas, distribuídas perpendicularmente à nervura primária, margem foliar lisa

13. Estípulas inteiras, 4-aristada, lâmina foliar velutina .... 28. Psychotria vellosiana 13. Estípulas bipartidas, não aristadas, lâmina foliar glabra ..... 26. Psychotria sessilis

11. Lâminas foliares largas, relação comprimento/largura $2 / 1$, nunca $3 / 1$

14. Estípulas inteiras

15. Inflorescências sésseis, glomeriformes

20. Psychotria cephalantha

15. Inflorescências pedunculadas, paniculiformes

16. Estípulas 4-aristadas, fruto liso 24. Psychotria myriantha

16. Estípulas lanceoladas; fruto multisulcado ..... 19. Psychotria carthagenensis 14. Estípulas bipartidas

17. Inflorescências pedunculadas

21. Psychotria conjugens

17. Inflorescências sésseis

18. Brácteas involucrais, paleáceas; cálice verde ... 22. Psychotria hastisepala

18. Brácteas não involucrais, sepalóides; cálice vermelho ... 25. Psychotria nuda

1. Ervas anuais ou perenes, prostradas ou eretas

19. Estípulas foliáceas

15. Galium hypocarpium

19. Estípulas não foliáceas

20. Estípulas inteiras ou bipartidas; flores distílicas

21. Ervas eretas; estípulas bipartidas; corola branca; ovário com um óvulo por lóculo

23. Psychotria hygrophiloides

21. Ervas prostradas; estípulas inteiras; corola violácea ou azulada; ovário com muitos óvulos por lóculo

22. Ervas glabras; lâmina foliar cordiforme

8. Coccocypselum krauseanum

22. Ervas pilosas; lâmina foliar lanceolada ou oval-lanceolada

23. Lâmina foliar velutina; inflorescências pedunculadas, com 10-20 flores

9. Coccocypselum lanceolatum

23. Lâmina foliar hirsuta; inflorescências sésseis, com 7-10 flores

7. Coccocypselum hasslerianum

20. Estípulas fimbriadas ou cerdosas; flores homostílicas

24. Inflorescências axilares unifloras

13. Diodia teres

24. Inflorescências em glomérulos terminais ou axilares

25. Ervas prostradas; flores hexâmeras; ovário tricarpelar; fruto esquizocarpo

25. Ervas eretas; flores tetrâmeras; ovário bicarpelar; fruto cápsula

29. Richardia grandiflora

26. Ervas muito ramificadas; estípulas cerdosas; fruto cápsula com deiscência circuncisa

16. Mitracarpus frigidus

26. Ervas pouco ramificadas; estípulas fimbriadas; fruto cápsula com deiscência septicida 
27. Ervas glabras; ramos bifurcados no ápice; estigma subséssil

27. Ervas pilosas; ramos não bifurcados no ápice; estigma não subséssil

28. Lamina foliar elíptico-ovada; inflorescência com 3-7 flores; duas brácteas foliáceas; estigma bífido ..... 4. Borreria latifolia

28. Lamina foliar lanceolada; inflorescência com mais de 15 flores; mais de duas brácteas foliáceas; estigma capitado, levemente bilobado 29. Ramos avermelhados; cálice com quatro sépalas; filete retorcido

2. Borreria capitata

29. Ramos verdes; cálice com duas sépalas; filete não retorcido .. B. Borreria verticillata

1. Bathysa nicholsonii K. Schum., Fl. Bras. 6(6): 236. 1886.

Fig. 1-2

Árvores $7 \mathrm{~m}$. Ramos crassos, tetragonais. Pecíolo rasamente canaliculado, setoso, 1,2-1,9 cm; lâmina lanceolada, $16-45 \times 10-18 \mathrm{~cm}$, superfície ventral glabra e dorsal setosa, nervura primária proeminente na superfície dorsal, ápice agudo, base obtusa; estípulas persistentes, lanceoladas, 2-3,3×1,5-2 cm. Inflorescências em cimeiras paniculiformes terminais; flores sésseis, 4-meras; cálice $3 \mathrm{~mm}$, lobos largo-ovados; corola hipocrateriforme, amarelo-esverdeada, 4-5 mm, externamente com linha vertical de tricomas abaixo da incisão dos lobos, lobos eretos, 2-2,5 mm, planos, largo-ovados; filetes levemente complanados com tufos de tricomas na metade inferior, 1,5-2 $\mathrm{mm}$; anteras elípticas, basifixas; estilete 2,5-3 mm; estigma bífido. Fruto cápsula septicida, elíptica ou obcônica, 4-5x 2,5-3 mm; sementes comprimidas, castanhas.

Material examinado: BRASIL. Minas Gerais: Viçosa, RFMP, trilha principal, 2/XI/2001, fl., Pereira \& Rossi 32 (VIC); Trilha do aceiro, 26/II/2001, fr., Pereira \& Basílio 67 (VIC).

Bathysa nicholsonii distribui-se no Rio de Janeiro e Minas Gerais (Germano Filho 1999). Na RFMP, ocorrem vários indivíduos distribuídos ao longo da trilha principal e trilha do aceiro. Floresceu de outubro a março, frutificando até julho. $\mathrm{Na}$ área de estudo é facilmente reconhecida por apresentar lâmina foliar e estípula de grandes dimensões.

2. Borreria capitata (Ruiz \& Pav.) DC., Prodr. 4: 545. 1830.

Fig. 3-4

Ervas anuais ou perenes, eretas, $30-50 \mathrm{~cm}$. Ramos novos tetragonais, avermelhados, hirsutos. Folhas sésseis; lâmina lanceolada, 3-2×0,4-0,6 cm, hirsuta, nervuras primária e secundárias proeminentes, ápice agudo, base atenuada; estípulas 6-9 fimbriadas. Inflorescências sésseis, em glomérulos terminais ou axilares com mais de 15 flores, envolvidos por 4 brácteas iguais duas a duas, lanceoladas; flores sésseis, 4-meras; cálice com 4 lobos iguais, lanceolados a espatulados, ciliados, 2-3,5 mm; corola infundibuliforme, branca a azulada, 3-4,5 mm, externamente pubescente, internamente com anel de tricomas próximo à base do tubo, lobos triangulares, 1-1,5 mm, recurvos, barbelados; estames exsertos filetes retorcidos, 1-2,5 mm,; anteras elípticas; ovário com o terço superior subviloso; estilete 2-4 mm; estigma captado a levemente bilobado. Fruto cápsula septicida, ovóide-lanceolada, 2-3×1-1,5 mm; sementes plano-convexas, elípticas, superfície dorsal fortemente convexa, sulcada transversalmente e superfície ventral com profundo sulco longitudinal.

Material examinado: BRASIL. Minas Gerais: Viçosa, RFMP, trilha do aceiro, 7/III/2002, fl., Pereira et al. 70 (VIC); Trilha do aceiro, 2/VIII/2002, fl., fr., Pereira \& Valente 93 (VIC).

Segundo Cabral \& Bacigalupo (1999), Borreria capitata ocorre na Venezuela, Guiana Francesa, Suriname, Brasil, Peru e Bolívia. No Brasil, encontrase distribuída na Bahia, Minas Gerais, Rio de Janeiro, São Paulo, Distrito Federal e Rio Grande do Sul (Dimitri 1959; Porto et al. 1977). Na RFMP, foram encontradas várias populações, todas ao longo da trilha do aceiro. Floresceram e frutificaram de setembro a abril. Das espécies de Borreria amostradas na RFMP, é a única que apresenta ramos avermelhados, sendo essa característica muito importante para o reconhecimento dessa espécie no campo e mesmo quando herborizada. Além disso, esta espécie distingue-se das demais pelos seus longos ramos, inflorescências em glomérulos multifloros e a semente com a superfície dorsal sulcada transversalmente. 
3. Borreria eryngioides Cham. et Schltdl., Linnaea 3: 316.1828.

Fig. 5-6

Ervas perenes, eretas, 10-20 cm. Ramos tetragonais, bifurcados no ápice, geralmente glabros. Folhas sésseis; lâmina linear-lanceolada, 1-2,5× 0,2-0,6 cm, hirsuta, nervuras secundárias inconspícuas, ápice agudo, base atenuada, margem às vezes revoluta; estípulas 9-11 fimbriadas. Inflorescências sésseis, em glomérulos axilares e terminais com menos que 15 flores; 4 brácteas foliáceas, iguais duas a duas; flores sésseis, 4-meras; cálice com 4 lobos iguais, triangulares, 1-2 mm, com pequenos dentes entre si; corola infundibuliforme, branca, 1-2,5 $\mathrm{mm}$, externamente glabra ou mais raramente pubescente, internamente com anel de pêlos, lobos triangulares, 0,5-0,8 mm, ápice recurvo; estames exsertos; anteras subsésseis, subelipsóides; estilete $0,2 \mathrm{~mm}$, incluso; estigma subséssil, levemente bilobado. Fruto cápsula septicida, subglobosa, 1,5-2×1-1,5 mm; sementes plano-convexas, subelipsóides, com superfície dorsal foveolada e ventral com profundo sulco longitudinal.

Material examinado: BRASIL. Minas Gerais: Viçosa, RFMP, trilha do aceiro, 21/III/2002, fl., fr., Pereira \& Valente 74 (VIC).

Borreria eryngioides ocorre na Bolívia, Paraguai, Brasil, Argentina e Uruguai (Bacigalupo \& Cabral 1996). No Brasil, é encontrada em Minas Gerais, Rio de Janeiro e Rio Grande do Sul (Dimitri 1959; Porto et al. 1977). Na RFMP, foi observada uma única população, em local ensolarado e seco, próximo à sede da Reserva. Floresceu e frutificou de outubro a março. Constituem caracteres diagnósticos importantes as anteras e os estigmas subsésseis, bem como, as sementes com a superfície dorsal foveolada.

4. Borreria latifolia (Aubl.) K. Schum., Fl. Bras. 6(6): 61.1888.

Fig. 7

Ervas anuais, eretas, $30-50 \mathrm{~cm}$. Ramos novos tetragonais, hirsutos. Folhas sésseis ou subsésseis; lâmina elíptico-ovada, 2,5-4×1,5-2 cm, hirsuta, nervuras primária e secundárias proeminentes na superfície dorsal, ápice agudo, base atenuada; estípulas 5-7 fimbriadas, pubescentes. Inflorescências sésseis, em glomérulos axilares 3-7 flores; duas brácteas foliáceas; flores sésseis, 4-meras; cálice com 4 lobos iguais, triangulares, $2 \mathrm{~mm}$, pubescentes; corola infundibuliforme, branca ou azulada, 3-3,5 mm, glabra, lobos ovais, 1-1,5 mm, ciliados, ápice recurvo; estames exsertos; anteras elípticas, subsésseis; ovário bilocular, um óvulo por lóculo; estilete exserto, 5-7 mm; estigma bífido. Fruto cápsula septicida, subglobosa, 3-4×2-3 mm, pubescente; sementes plano-convexas, elípticas, superfície dorsal fortemente convexa, reticulada, superfície ventral com profundo sulco longitudinal.

Material examinado: BRASIL. Minas Gerais: Viçosa, RFMP, trilha do aceiro, 7/III/2002, fl., fr., Pereira et al. 71 (VIC).

Borreria latifolia ocorre no México, Antilhas e América do Sul (Burger \& Taylor 1993). No Brasil distribui-se desde o Amazonas até o Rio Grande do Sul (Kissmann \& Groth 2000; Dimitri 1959). Na RFMP, está representada por muitos indivíduos, todos ocorrendo ao longo da trilha do aceiro. Floresceram e frutificaram de outubro a março. Esta espécie diferencia-se das demais do gênero pelas folhas largas, hirsutas e pelos glomérulos axilares guarnecidos por duas brácteas foliáceas.

5. Borreria verticillata (L.) G. Mey., Prim. Fl. Esseq. 83, t.1. 1818.

Fig. 8-9

Ervas perenes, eretas, $20-30 \mathrm{~cm}$. Ramos subcilíndricos a tetragonais, densamente ramificados, seríceos. Folhas sésseis; lâmina lanceolada, 3,5-5,5x 0,5-1 cm, seríceas, nervura primária proeminente na superfície dorsal, ápice agudo, base atenuada; estípulas 5-6 fimbriadas. Inflorescências sésseis, em glomérulos terminais e axilares com mais que 15 flores; 4 a 6 brácteas foliáceas iguais; flores sésseis, 4-meras; cálice com 2 lobos espatulados, 2-4 mm, pubescentes, com dentes hialinos entre eles; corola infundibuliforme, branca, 2-3 $\mathrm{mm}$, externamente glabra, internamente com anel de tricomas na metade do tubo, lobos com o ápice sub-recurvado de comprimento igual ao do tubo; estames exsertos; filetes 1,5-1,8 mm; anteras elípticas; estilete 3-4 mm, exserto; estigma capitado, levemente bilobado. Fruto cápsula septicida, subglobosa, 1,5-2,3×1-1,5 mm; sementes plano-convexas, subelipsóides, superfície dorsal fortemente convexa, reticulada, superfície ventral escavada, com sulco longitudinal.

Material examinado: BRASIL. Minas Gerais: Viçosa, RFMP, trilha principal, 3/VII/2001, fl., Pereira et al. 5 (VIC); trilha do aceiro, 28/III/2002, fl., fr., Pereira et al. 77 (VIC).

Borreria verticillata distribui-se pelo Velho Mundo, Sul dos Estados Unidos até o sul da América 
do Sul (Burger \& Taylor 1993). No Brasil, distribui-se desde o Amazonas até o Rio Grande do Sul (Dimitri 1959). Na RFMP, esta espécie é a mais comum, abundante em número de indivíduos e amplamente distribuída, ocorrendo no interior da mata e trilha do aceiro. Floresceu e frutificou o ano todo. Na RFMP, pode ser reconhecida pelas inflorescências em glomérulos terminais e axilares, multifloros, envolvidos por quatro ou mais brácteas foliáceas iguais e cálice com dois lobos.

6. Chiococca alba (L.) Hitchc., Ann. Rept. Missouri Bot. Gard. 4: 94. 1893.

Fig. 10

Arbusto escandente. Ramos cilíndricos, glabros. Pecíolo subcilíndrico, 3-5mm; lâmina ovada, 4-7,5× 2,5-4 cm, glabra, nervura primária proeminente na superfície dorsal, ápice cuspidado, base atenuada; estípulas triangulares, ápice aristado. Inflorescências em cimeiras paniculiformes, axilares, dispostas unilateralmente; pedúnculo $2-3 \mathrm{~cm}$, levemente pubescente; flores 5-meras, pedicelo 1-1,5 $\mathrm{mm}$; cálice $3 \mathrm{~mm}$, lobos triangulares ciliados; corola campanulada, amarela a avermelhada, 5-10 $\mathrm{mm}$, externamente glabra, internamente pilosa no terço inferior, lobos 3-4 mm, triangulares; estames inclusos, filetes pilosos, 1,5 mm; anteras lanceoladas; estilete exserto, 5-7 mm; estigma bilobado. Fruto drupáceo, comprimido lateralmente, 4-5×3-4 mm, branco na maturidade; sementes comprimidas, elípticas, lisas, castanhas.

Material examinado: BRASIL. Minas Gerais: Viçosa, RFMP, trilha principal, 17/I/2002, fl., Pereira et al. 46 (VIC); trilha lateral, 2/XI/2001, fr., Pereira \& Rossi 12 (VIC).

Chiococca alba distribui-se do Sul dos Estados Unidos até o México, América Central, América do Sul e Antilhas (Burger \& Taylor 1993). No Brasil, ocorre desde Pernambuco até o Rio Grande do Sul (Smith \& Downs 1956; Jung-Mendaçolli 1994). Na RFMP, distribui-se na trilha principal, principalmente, nas áreas mais perturbadas. Floresceu de dezembro a fevereiro e frutificou de fevereiro a maio. Os caracteres diagnósticos importantes são as inflorescências axilares em cimeiras paniculiformes com flores amarelas dispostas unilateralmente e os frutos brancos comprimidos lateralmente.

7. Coccocypselum hasslerianum Chodat, Bull. Herb. Boissier., Sér. 2,4: 169. 1904.

Fig. 13-14

Ervas perenes, prostradas. Ramos cilíndricos, hirsutos. Pecíolo semicilíndrico, 1,5-2 cm, hirsuto; lâmina oval-lanceolada, 8-10×3,5-4 cm, hirsuta, nervuras primária e secundárias proeminentes na superfície dorsal, 6-8 pares de nervuras secundárias, ápice agudo, base obtusa; estípulas filiformes. Inflorescências sésseis, em glomérulos terminais, 7-10 flores, densamente pubescentes; flores sésseis, 4-meras, distílicas; cálice 4-5 mm, lobos lineares 2-3 mm, hirsutos; corola infundibuliforme, violácea, 5-6 mm, hirsuta, lobos triangulares, $1,5 \mathrm{~mm}$; estames inclusos ou exsertos; filetes semicilíndricos, $1,5 \mathrm{~mm}$; anteras lanceoladas; ovário bilocular, pluriovulado; estilete incluso ou exserto, $4 \mathrm{~mm}$; estigma bífido. Fruto bacáceo, obovóide, hirsuto, 1-1,5×0,8-1 cm, pericarpo carnoso, azul ou violáceo; sementes plano-convexas, castanhas, superfície dorsal reticulada, superfície ventral com sulco longitudinal.

Material examinado: BRASIL. Minas Gerais: Viçosa, RFMP, trilha do aceiro, 10/VI/2002, fl., Pereira et al. 84 (VIC).

Coccocypselum hasslerianum distribui-se no Paraguai, Argentina, Brasil, desde o Amazonas até o Rio Grande do Sul (Andersson 1992). Na RFMP, ocorre na parte mais úmida do aceiro. Distingue-se das demais pelo indumento hirsuto, lâmina foliar com 6-8 pares de nervuras secundárias.

8. Coccocypselum krauseanum Standl., Field Mus. Nat. Hist., Bot. Ser. 8(3): 164. 1930.

Fig. 11-12

Ervas prostradas. Ramos cilíndricos, glabros. Pecíolo cilíndrico, $3-5 \mathrm{~cm}$, glabro; lâmina cordiforme, 2-6×2,3-5,5 cm, glabra, nervura primária proeminente em ambas as superfícies, 6-8 pares de nervuras secundárias, ápice agudo, base obtusa, margem ciliada; estípulas filiformes. Inflorescências sésseis, em glomérulos terminais, 3-6 flores; flores sésseis, 4-mera, distílicas; cálice $8 \mathrm{~mm}$, lobos linearlanceolados, $5 \mathrm{~mm}$, glabros; corola infundibuliforme, $1 \mathrm{~cm}$, violácea, glabra, lobos triangulares, $2 \mathrm{~mm}$; estames inclusos ou exsertos; filetes $1,5 \mathrm{~mm}$; anteras lanceoladas; ovário bilocular, pluriovulado; estilete incluso ou exserto, $6 \mathrm{~mm}$; estigma bífido. Fruto bacáceo, elipsóide, glabro, 1-1,5×0,8-1 cm, cálice persistente, pericarpo carnoso, violáceo; sementes plano-convexas, castanhas, superfície dorsal lisa, superfície ventral com sulco longitudinal.

Material examinado: BRASIL. Minas Gerais: Viçosa, RFMP, trilha principal, 2/VIII/2002, fl., fr., Pereira et al. 86 (VIC). 
Coccocypselum krauseanum distribui-se pela Colômbia, Equador, Peru, Brasil, desde a Bahia até o Rio Grande do Sul (Andersson 1992). Na RFMP, ocorrem poucos indivíduos na trilha principal, na área mais úmida da mata. Das espécies de Coccocypselum amostradas, é a única totalmente glabra e a que apresenta maiores dimensões de pecíolo e corola.

9. Coccocypselum lanceolatum (Ruiz \& Pav.) Pers., Syn. Pl. 1: 132, 1805.

Fig. 15-16

Ervas perenes, prostradas. Ramos cilíndricos, velutinos. Pecíolo semicilíndrico, 0,8-1,5 cm, velutino; lâmina oval-lanceolada, 3-4×2-3,5 cm, velutina, nervuras primária e secundárias proeminentes, 7-12 pares de nervuras secundárias, ápice agudo a obtuso, base obtusa; estípulas filiformes. Inflorescências pedunculadas em glomérulos terminais, 10-12 flores, densamente pubescentes; brácteas foliáceas 1-3 mm; flores sésseis, 4-mera, distílicas; cálice $2 \mathrm{~mm}$, lobos ovais, $1 \mathrm{~mm}$, reflexos, velutinos; corola infundibuliforme, azulada, 3,5-4 mm, velutina, lobos triangulares, $2 \mathrm{~mm}$; estames inclusos ou exsertos; filetes $1 \mathrm{~mm}$; anteras lanceoladas; ovário bilocular, pluriovulado; estilete incluso ou exserto, 2,5 mm; estigma bífido. Fruto bacáceo, elipsóide ou obovóide, 2-2,5×1-1,5 cm, azul brilhante, sementes orbiculares, plano-convexas, castanhas, superfície dorsal muricada, superfície ventral com sulco longitudinal.

Material examinado: BRASIL. Minas Gerais: Viçosa, RFMP, trilha do aceiro, 26/II/2002, fl., Pereira \& Basílio 68 (VIC); trilha principal, 26/VIII/2002, fl., fr., Pereira \& Valente 89 (VIC).

Coccocypselum lanceolatum apresenta ampla distribuição na região neotropical, ocorrendo desde o Sul do México até a Argentina, exceto na região amazônica (Andersson 1992). No Brasil, encontra-se desde Minas Gerais até o Rio Grande do Sul (Smith \& Downs 1956). Na RFMP, distribui-se pelo interior da mata e aceiro, preferencialmente em locais sombreados e úmidos. Floresceu e frutificou o ano todo. Das espécies de Coccocypselum amostradas na RFMP, é a única que apresenta indumento velutino, inflorescências pedunculadas e cálice reflexo. A presença de cálice reflexo foi referida por Steyermark $(1967$; 1974) como um caráter importante na delimitação desta espécie.

10. Coussarea triflora Müll. Arg., Flora 58: 468. 1875. Fig. 18-20

Arbustos 1,5 m. Ramos cilíndricos, glabros. Pecíolo semicilíndrico, 0,8-2 cm; lâmina lanceolada, $5-9 \times 1-2 \mathrm{~cm}$, glabra, nervura primária proeminente na superfície dorsal, ápice cuspidado, base obtusa; estípulas triangulares, ápice agudo. Inflorescências em cimeiras pedunculadas, trifloras, terminais, pedúnculo verde; brácteas foliáceas; flores subsésseis, 4-meras; cálice truncado, 3-4 mm, glabro; corola tubulosa, branca, 15-20 mm, glabra, lobos lanceolados, 7-8 mm; estames inclusos; filete $1 \mathrm{~mm}$; anteras lanceoladas; ovário unilocular, dois óvulos, placentação basal; estilete exserto, 8-10 mm. Fruto bacáceo, elipsóide, monospérmico, 6-8 $\times 4-5 \mathrm{~mm}$, pericarpo verde, muricado; sementes elípticas, lisas, esbranquiçadas.

Material examinado: BRASIL. Minas Gerais: Viçosa, RFMP, trilha principal, 28/III/2002, fr., Pereira et al. 76 (VIC); trilha lateral, 2/VIII/2002, fl., Pereira \& Valente 94 (VIC).

Segundo Andersson (1992), esta espécie ocorre desde o Pará até o Rio Grande do Sul. Na RFMP, ocorre preferencialmente no interior da mata, principalmente em locais mais sombreados. Floresceu de dezembro a fevereiro e frutificou de março a julho. Coussarea triflora distingue-se facilmente de C. verticillata pelo tipo de filotaxia, e pelas inflorescências trifloras, protegidas por duas brácteas foliáceas que cobrem toda a inflorescência e fruto com pericarpo muricado verde.

11. Coussarea verticillata Müll. Arg., Flora 58:467. 1875. Fig. 17

Árvores 6m. Ramos trigonais, glabros. Folhas verticiladas, Pecíolo trigonal, 1-2 cm; lâmina obovallanceolada, $15-2 \times 4-7 \mathrm{~cm}$, glabra, nervuras primária e secundárias proeminentes na superfície dorsal, ápice mucronado, base atenuada; estípulas triangulares de ápice obtuso. Inflorescências em cimeiras pedunculadas, paniculiformes, terminais, pedúnculo verde; brácteas ausentes; flores sésseis; cálice truncado, 3-4 mm, glabro; corola tubulosa, branca, 6-7 mm, glabra, lobos lanceolados, 1,5-2 mm; estames inclusos; filetes 2-2,8 mm; anteras lanceoladas; ovário unilocular, dois óvulos, placentação basal; estilete cilíndrico, exserto, 6-7 mm. Fruto bacáceo, globoso, monospérmico, 5-6×3,5-4 mm, pericarpo preto, liso; sementes globosas, lisas, castanhas.

Material examinado: BRASIL. Minas Gerais: Viçosa, RFMP, trilha principal, 26/II/2002, fr., Pereira \& Basílio 60 (VIC).

Coussarea verticillata ocorre desde Minas Gerais até o Rio Grande do Sul (Andersson 1992). Na RFMP, está representada por apenas dois indivíduos, 

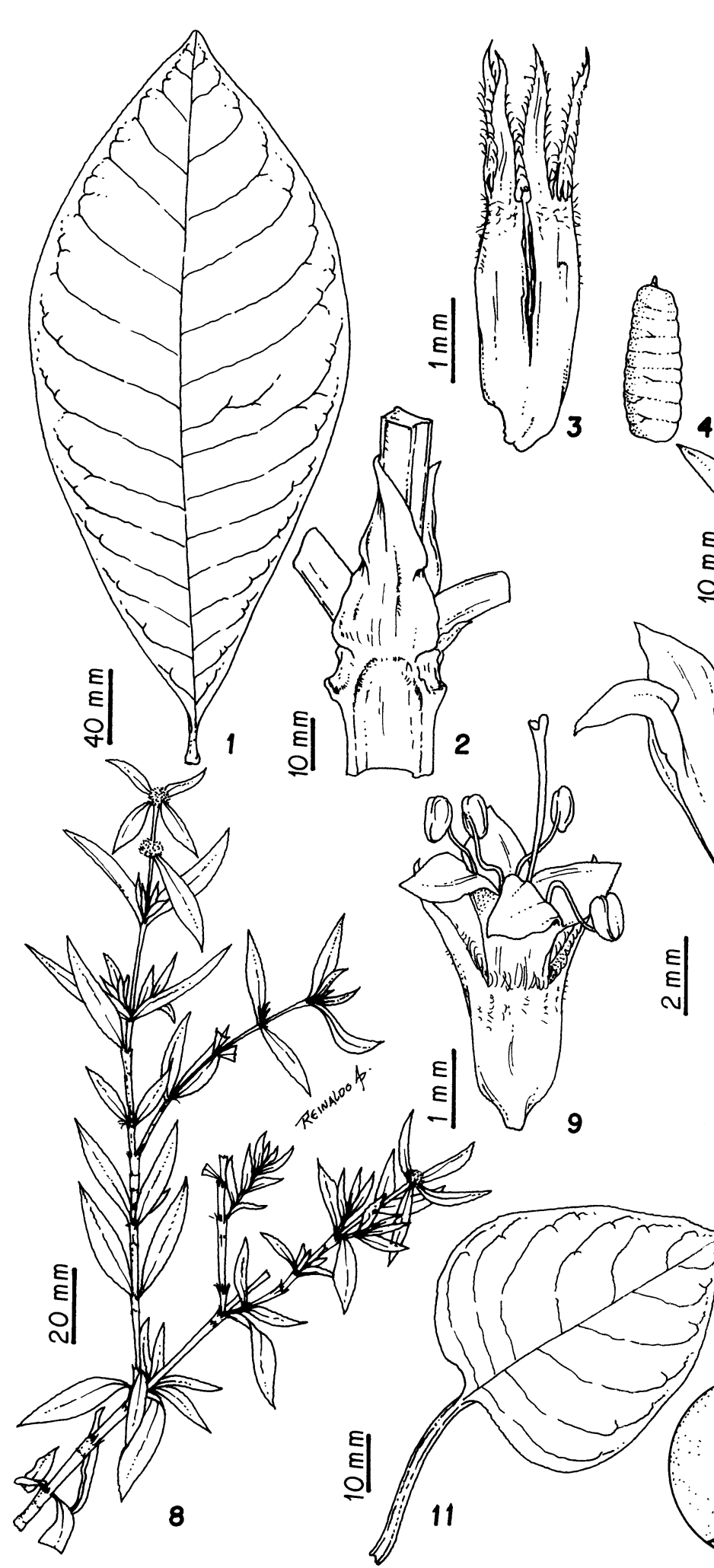

$(1)$
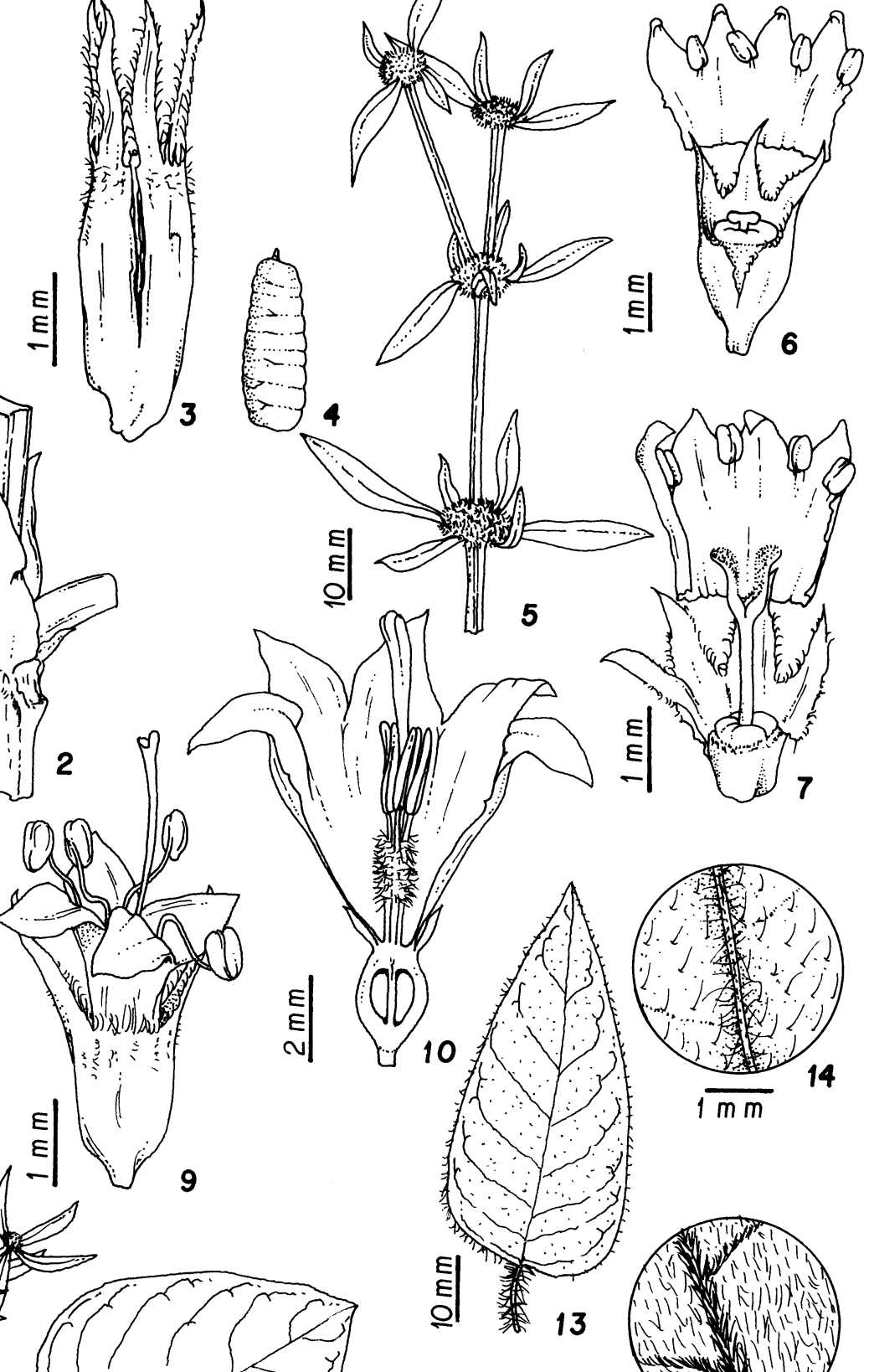

$1 \overline{m m}$
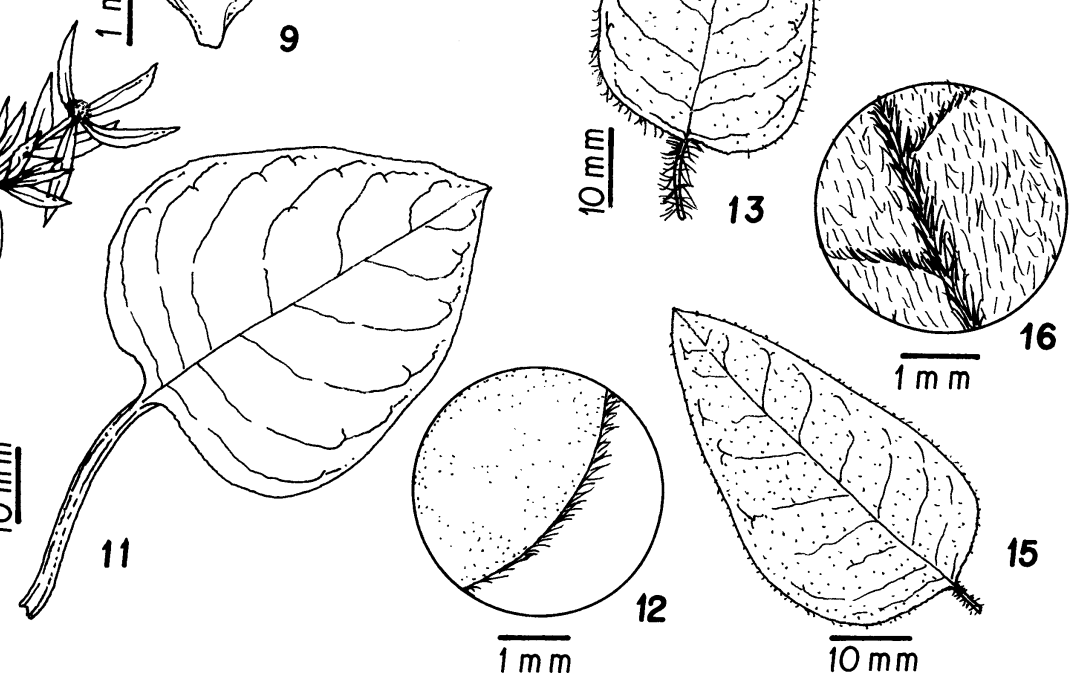

Figuras 1-16. Bathysa nicholsonii (Pereira et al. 32). 1. Folha. 2. Estípulas. 3-4. Borreria capitata (Pereira et al. 82). 3. Fruto. 4. Semente. 5-6. Borreria eryngioides (Pereira et al. 79). 5. Ramos. 6. Flor. 7. Flor - Borreria latifolia (Pereira et al. 71). 8-9. Borreria verticillata(Pereira et al. 5). 8. Ramos. 9. Flor. 10. Flor - Chiococca alba (Pereira et al. 46). 11-12. Coccocypselum krauseanum (Pereira \& Valente 86). 11. Folha. 12. Detalhe da margem foliar. 13-14. Coccocypselum hasslerianum (Pereira \& Valente 87). 13. Folha. 14. Detalhe da folha. 15-16. Coccocypselum lanceolatum (Pereira \& Basílio 68). 15. Folha. 16. Detalhe da folha. 
ambos encontrados na trilha principal, próximo a área mais alterada. Dentre as Rubiaceae arbóreas amostradas, é a única que apresenta filotaxia verticilada.

12. Coutarea hexandra (Jacq.) K. Schum., Fl. Bras. 6(6): 196, 1889.

Fig. 21

Árvores $5 \mathrm{~m}$. Ramos cilíndricos, vilosos. Pecíolo semicilíndrico, 0,5-1 cm, viloso; lâmina elíptica, 2-3× $3-3,5 \mathrm{~cm}$, glabra na superfície ventral e vilosa na superfície dorsal, principalmente sobre a nervura primária, nervura primária proeminente em ambas as superfícies, ápice cuspidado, base obtusa; estípulas triangulares, ápice agudo. Inflorescências em cimeiras paniculiformes, terminais ou axilares; brácteas lanceoladas ou subuladas; flores $5-7 \mathrm{~cm}$, curto pediceladas, 6-meras, zigomorfas; cálice $2,5-4 \mathrm{~cm}$, lobos iguais, subulados, $2 \mathrm{~mm}$, pubescentes, com glândulas na base dos lobos; corola campanulada, ligeralmente falcada, rosa, $4-7 \mathrm{~cm}$, pubescente, lobos obtusos ou agudos, $2-3 \mathrm{~cm}$; estames exsertos, filetes 5-7 cm; anteras lanceoladas, $2,5 \mathrm{~cm}$; estilete exserto, $5-7 \mathrm{~cm}$; estigma bífido. Fruto cápsula loculicida, comprimida, obovada, resistente, lenticelada, 1,8-2,5× 1-1,5 cm, duas valvas abertas no ápice; sementes oblongas, castanhas, com alas inteiras e onduladas.

Material examinado: BRASIL. Minas Gerais: Viçosa, RFMP, trilha do aceiro, 26/II/2002, fr., Pereira \& Basílio 65 (VIC); trilha do aceiro, 2/XI/2001, fl., Pereira \& Rossi 27 (VIC).

Coutarea hexandra distribui-se do México até a Argentina (Dwyer 1980). No Brasil, ocorre do Amazonas ao Rio Grande do Sul (Lorenzi 1998). Na RFMP, está representada por poucos indivíduos distribuídos na trilha do aceiro, em locais secos e ensolarados. Floresceu de novembro a janeiro e frutificou de fevereiro a maio. Caracteriza-se pelos ramos lenticelados, flores grandes, fruto capsular e semente alada.

\section{Diodia teres Walter, Fl. Carol. 87. 1788.}

Fig. 22

Ervas anuais, eretas, $10-40 \mathrm{~cm}$. Ramos tetragonais, vilosos. Folhas sésseis, lâmina linear-lanceolada, $1,5-2 \times 0,4-0,5 \mathrm{~cm}$, hirsuta, nervura primária proeminente em ambos as superfícies e secundárias inconspícuas, ápice acuminado, base atenuada, margem inteira. Inflorescências unifloras, axilares; flores sésseis, 4-meras; cálice 1,5-3 mm, com 4 lobos triangulares, margem ciliada; corola tubulosa, rosa, 4-6 mm, externamente pouco pilosa e internamente com um anel de tricomas na porção inferior do tubo, lobos oblongos ou deltóides, $2 \mathrm{~mm}$; estames inclusos; filetes $0,5 \mathrm{~mm}$; anteras oblongas; estilete exserto, $4 \mathrm{~mm}$; estigma bilobado. Fruto esquizocarpo, ovado, 2-4,5x 2-3 mm, pericarpo resistente, castanho, cerdoso; sementes ovóides, plano-convexas, castanhas, levemente brilhantes, superfície dorsal lisa, superfície ventral com sulco longitudinal.

Material examinado: BRASIL. Minas Gerais: Viçosa, RFMP, trilha do aceiro, 26/II/2002, fl., fr., Pereira \& Basílio 69 (VIC).

Diodia teres ocorre no sudeste dos Estados Unidos, América Central e América do Sul (Dwyer 1980; Kissmann \& Groth 2000). No Brasil, é encontrada desde o Amazonas até o Rio Grande do Sul (Kissmann \& Groth 2000). Na RFMP, foram encontrados poucos indivíduos, todos distribuídos ao longo da trilha do aceiro. Floresceu e frutificou durante o ano todo. Caracteriza-se por seu porte reduzido, folhas sésseis, linear-lanceoladas, hirsutas, nervura primária proeminente e secundárias inconspícuas; flores rosas, solitárias, axilares, sésseis; fruto formado por dois mericarpos indeiscentes.

14. Faramea multiflora A. Rich. ex DC., Prodr. 4: 497. 1830.

Fig. 23-24

Arbustos 1,5 m. Ramos cilíndricos, glabros. Folhas subsésseis, pecíolo, 0,5-1 cm, lâmina lanceolada, 7-14×2-4,5 cm, glabra, nervura primária proeminente na superfície dorsal, ápice acuminado, base obtusa; estípulas persistentes, concrescidas, ápice aristado. Inflorescências em cimeiras paniculiformes, terminais, pedúnculo azulado; brácteas ausentes; flores 4-meras, pedicelos delgados, 2-3 mm; cálice campanulado, $2 \mathrm{~mm}$, lobos subtriangulares, glabros; corola tubulosa, azul, 1,5-2 cm, glabra, lobos lanceolados, quase do tamanho do tubo; estames inclusos; filetes $0,5 \mathrm{~mm}$; anteras lanceoladas, $2 \mathrm{~mm}$; ovário unilocular, biovular; estilete incluso, $2 \mathrm{~mm}$; estigma bífido. Fruto bacáceo, comprimido-globoso, 4-5×6-7 mm, azul na maturidade; sementes lisas, posicionadas horizontalmente na base, com a parte inferior transversalmente sulcada.

Material examinado: BRASIL. Minas Gerais: Viçosa, RFMP, trilha principal, 26/II/2002, fl., fr., Pereira \& Basílio 62 (VIC); trilha do aceiro, 2/XI/2001, fl., Pereira \& Rossi 33 (VIC).

Faramea multiflora distribui-se pela Costa Rica, Brasil e Bolívia (Burger \& Taylor 1993). No Brasil, ocorre desde o Amazonas até o Rio Grande do Sul 
(Andersson 1992). Na RFMP, está representada por vários indivíduos encontrados tanto no interior da mata como na trilha do aceiro. Floresceram de outubro a janeiro e frutificaram de janeiro abril. Das espécies de Rubiaceae amostradas na RFMP, é a única que apresenta inflorescências completamente azuis, inclusive os pedúnculos.

15. Galium hypocarpium (L.) Endl. ex Greseb. Fl. Brit. W. L. 4: 351. 1861.

Fig. 47

Ervas perenes, prostradas, $30 \mathrm{~cm}$. Ramos semitetragonais, hirsutos. Folhas sésseis, lâmina oblongolanceolada, 0,8-1,3×0,3-0,7 cm, hirsuta, nervura primária proeminente na superfície dorsal, nervuras secundárias inconspícuas, ápice agudo, base obtusa, parcialmente revoluta; estípulas foliáceas; Inflorescências axilares, 1-2 flores; 4 brácteas sepalóides, 2-3 mm, involucrais; flores 4-meras, pedicelos 0,2-1 cm; corola rotácea, branca, 2-3 mm, externamente pilosa, internamente glabra, lobos triangulares, 1,5 mm, ciliados; estames exsertos; filetes 2-4 mm; anteras oblongas; 2 estiletes exsertos, 1-2 mm; estigma 2, capitados. Fruto bacáceo, obovado, 2-3×3,3-3,6 mm, alaranjado na maturidade, piloso; sementes planoconvexas, castanho-claras, superfície dorsal lisa, superfície ventral com sulco longitudinal.

Material examinado: BRASIL. Minas Gerais: Viçosa, RFMP, trilha principal,17/II/2002, fl., fr., Pereira et al. 56 (VIC).

Esta espécie distribui-se pelo México, América Central, América do Sul e Antilhas (Dwyer 1980). No Brasil, ocorre em São Paulo, Minas Gerais, Santa Catarina e Rio Grande do Sul (Dempster 1981; 1982; 1990). Na RFMP, foram encontrados alguns indivíduos ao longo da trilha principal. Floresceu e frutificou praticamente o ano todo. Caracteriza-se pelas estípulas foliáceas, 1-2 flores com quatro brácteas sepalóides, do mesmo tamanho da corola e frutos alaranjados.

16. Mitracarpus frigidus (Willd. ex Roem. \& Schult.) K. Schum., Fl. Bras. 6(6): 81. 1888.

Fig. 25-26

Ervas perenes, eretas, $70 \mathrm{~cm}$. Ramos tetragonais, pilosos nos ângulos. Folhas subsésseis, verdeamareladas, lâmina elíptico-lanceolada, 3-8,5× 0,5-1,5 cm, hirsuta, nervuras primária e secundárias proeminentes na superfície dorsal, ápice agudo, base atenuada; estípulas persistentes, 6-9 cerdosas. Inflorescências em glomérulos terminais e axilares, multifloras; 4 brácteas, lanceoladas; flores sésseis, 4-meras; cálice com 4 lobos triangulares, iguais dois a dois; corola tubulosa, branca, 2-2,5 mm, glabra, internamente com um anel de tricomas na metade do tubo, lobos oval-triangulares 0,6-1,1 mm; estames exsertos; filetes 0,3-0,5 mm; anteras subelipsóides; estilete exserto, $5 \mathrm{~mm}$; estigma bífido. Fruto cápsula, subglobosa, deiscência circuncisa, $1 \times 0,6 \mathrm{~mm}$, pericarpo coriáceo, com pilosidade translúcida na metade superior; sementes subelipsóides, castanhas, planoconvexas, superfície ventral com depressão em forma de $\mathrm{Y}$ de coloração esbranquiçada.

Material examinado: BRASIL. Minas Gerais: Viçosa, RFMP, trilha do aceiro, 3/VII/2001, fl., fr., Pereira et al. 7 (VIC).

Mitracarpus frigidus distribui-se na da América Tropical e Antilhas. No Brasil, distribui-se desde o Amazonas até o Rio Grande do Sul (Andersson 1992; Kissmann \& Groth 2000). Na RFMP, foi encontrada na trilha do aceiro. Floresceu e frutificou de dezembro a junho. Esta espécie é vegetativamente muito semelhante às espécies do gênero Borreria, entretanto, é possível distinguí-la pelos ramos pilosos somente nos ângulos, estípulas cerdosas, deiscência circuncisa do fruto e semente com depressão em forma de Y na superfície ventral.

17. Palicourea longepedunculata Gardner, J. Bot. 4: 109. 1845.

Fig. 27

Arbustos escandentes, $3 \mathrm{~m}$. Ramos cilíndricos, glabros. Pecíolo semicilíndrico, 1,5-2,3 cm; lâmina elíptico-lanceolada, 15-18×7-10 cm, glabra, nervura primária proeminente em ambas as superfícies, ápice acuminado a cuspidado, base obtusa; estípulas persistentes, bipartidas, lanceoladas. Inflorescências em cimeiras paniculiformes, axilares, pedúnculo $11-15 \mathrm{~cm}$, alaranjado; brácteas reduzidas; flores 5-meras, distílicas, curto-pediceladas, pedicelo 2-3 mm; cálice 1-2 mm, alaranjado, lobos triangulares, $0,5-0,7 \mathrm{~mm}$, glabros; corola tubulosa, gibosa, alaranjada, 7-13,5 mm, externamente glabra, internamente com anel de tricomas na base, lobos triangulares, $1-3 \mathrm{~mm}$, reflexos; estames inclusos ou exsertos; filetes 1-2,5 mm; anteras lanceoladas; estilete incluso ou exserto, 6-11,5 mm; estigma bífido. Fruto drupáceo, oblongo, multisulcado 4-6 $\times 3-5 \mathrm{~mm}$, preto na maturidade; sementes planoconvexas, castanhas, superfície ventral sulcada longitudinalmente, superfície dorsal 4-costada.

Material examinado: BRASIL. Minas Gerais: Viçosa, RFMP, trilha principal, 22/VIII/2001, fr., Pereira \& Valente 09 (VIC); trilha do aceiro, 


\section{6/II/2002, fl., Pereira \& Basílio 61 (VIC).}

Segundo Andersson (1992), P. longepedunculata distribui-se desde a Bahia até o Rio Grande do Sul. Na RFMP, está representada por vários indivíduos, distribuídos ao longo da trilha principal e na parte mais úmida do aceiro. Floresceu de janeiro a junho e frutificou de abril a agosto. Caracteriza-se pelo hábito escandente e inflorescências fortemente coloridas, axilares em cimeiras paniculiformes com pedúnculo de $11-15 \mathrm{~cm}$.

18. Palicourea marcgravii A. St.-Hil., Pl. Remarq. du Brésil. 22: 231. 1824.

Fig. 28-29

Arbustos eretos, $3 \mathrm{~m}$. Ramos cilíndricos, glabros. Pecíolo semicilíndrico, 3-6 mm, glabro; lâmina lanceolada, $8-11 \times 2-3,5 \mathrm{~cm}$, esparsamente pubescente sobre nervuras na superfície dorsal, nervura primária proeminente em ambas as superfícies, ápice agudo a acuminado, base obtusa ou truncada; estípulas persistentes, bipartidas, lanceoladas. Inflorescências em cimeiras corimbiformes, terminais, pedúnculo $3-4 \mathrm{~cm}$, avermelhado; brácteas muito reduzidas; flores 5-meras, distílicas, pedicelo 5-8 mm; cálice campanulado, avermelhado, 2-3 mm, lobos triangulares ou cuneados, pubescentes; corola tubulosa, gibosa, amarela nos $2 / 3$ basais passando a lilás no $1 / 3$ apical, $17-24,5 \mathrm{~mm}$, externamente pubescente, internamente com anel de tricomas na base, lobos triangulares, reflexos no ápice, 2,5-4 $\mathrm{mm}$; estames inclusos ou exsertos; filetes 1-2,5 mm; anteras lanceoladas; estilete incluso ou exserto, 10-22 mm; estigma bífido. Fruto drupáceo, comprimido, ovóide, 3-5×2-3,5 mm; sementes planoconvexas, castanhas, superfície ventral sulcada longitudinalmente, superfície dorsal lisa.

Material examinado: BRASIL. Minas Gerais: Viçosa, RFMP, trilha lateral, 6/XI/2001, fl., Valente 42 (VIC); trilha principal, 11/III/2002, fr., Pereira \& Valente 74 (VIC).

Palicourea marcgravii é amplamente distribuída no Brasil, exceto no extremo sul e no sertão do nordeste (Kissmann \& Groth 2000). Na RFMP, ocorre ao longo da trilha principal, sempre em locais muito sombreados. Floresceu de dezembro a fevereiro e frutificou de janeiro a abril. Destaca-se por suas flores amarelas na base e lilases no ápice.

19. Psychotria carthagenensis Jacq., Enum. Pl. Carib. 16. 1760.

Fig. 30

Arbustos 3 m. Ramos cilíndricos, glabros. Pecíolo semicilíndrico 1-1,5 cm, glabro; lâmina elípticolanceolada, $8-18 \times 5-8 \mathrm{~cm}$, glabra, nervuras primária e secundárias proeminentes na superfície dorsal, ápice agudo, base atenuada; estípulas caducas, inteiras, concrescidas, 1,5-2 cm, lanceoladas. Inflorescências pedunculadas, em cimeiras paniculiformes, terminais; brácteas triangulares caducas; flores sésseis, 5-meras, distílicas; cálice $0,5 \mathrm{~mm}$, truncado, pubescente; corola campanulada, branca, 5-7 mm, externamente pubescente, internamente com anel de tricomas na metade do tubo corolar, lobos levemente reflexos na flor em antese, com ápices recurvados; estames inclusos ou exsertos; filetes 0,8-2 mm; anteras elipsóides; estilete incluso ou exserto, 2,5-5 mm; estigma bífido. Fruto drupáceo, elipsóide, multisulcado, 6-8×4-6 mm, vermelho na maturidade; sementes plano-convexas, castanho-escuras, superfície ventral plana com profundo sulco longitudinal, superfície dorsal 4-costada.

Material examinado: BRASIL. Minas Gerais: Viçosa, RFMP, trilha principal, 22/IV/2002, fl., Pereira \& Valente 87 (VIC).

Psychotria carthagenensis distribui-se nos Estados Unidos, México, América Central, América do Sul e Antilhas (Burger \& Taylor 1993). No Brasil, ocorre desde o Amazonas até o Rio Grande do Sul (Andersson 1992). Na RFMP, está representada por poucos indivíduos distribuídos no interior da mata, sempre em locais sombreados. No campo, pode ser reconhecida pelas estípulas inteiras, grandes e lanceoladas e frutos multisulcados, vermelhos na maturidade.

20. Psychotria cephalantha (Müll. Arg.) Standl., Field Mus. Nat. Hist., Bot. Ser. 11(5): 235. 1936.

Fig. 31

Arbustos 3 m. Ramos cilíndricos, glabros. Pecíolo semicilíndrico, 0,5-1 cm, glabro; lâmina elípticolanceolada, $8-12 \times 2-5 \mathrm{~cm}$, glabra, nervuras primária e secundárias proeminentes na superfície dorsal, ápice acuminado, base atenuada; estípulas caducas, inteiras, triangulares, internamente com anel de pêlos. Inflorescências sésseis, glomérulos, terminais; brácteas triangulares, caducas; flores sésseis, 5-meras, distílicas; cálice $1,5 \mathrm{~mm}$, truncado, glabro; corola tubulosa, branca, 3-4,5 mm, externamente glabra, internamente com anel de tricomas na metade do tubo, lobos lanceolados, 1,5-2 mm, com ápices reflexos; estames inclusos ou exsertos; filetes $0,5-1 \mathrm{~mm}$; anteras lanceoladas; estilete piloso, incluso ou exserto, 1,5-4 mm; estigma bilobado. Fruto drupáceo, elipsóide, multisulcado, 5-7×4-6 mm, preto na maturidade; 
sementes plano-convexas, castanho-escuras, superfície ventral plana com sulco longitudinal, superfície dorsal 5-costada.

Material examinado: BRASIL. Minas Gerais: Viçosa, RFMP, trilha lateral, 17/I/2002, fl., Pereira et al. 53 (VIC); Rio de Janeiro: Macaé, 8/IV/1983, fr., Guedes et al. 199 (RB).

Psychotria cephalantha distribui-se na Venezuela, Trindade Tobago, Suriname, Guiana Francesa, Brasil e Bolívia (Andersson 1992). No Brasil, é encontrada desde a Bahia até o Rio Grande do Sul (Andersson 1992). Na RFMP, distribui-se no interior da mata, em locais sombreados. Floresceu de novembro a janeiro e frutificou de fevereiro a maio. Caracteriza-se pelas folhas largas e inflorescências globosas.

21. Psychotria conjugens Müll. Arg., Fl. Bras. 6(5): 26. 1881.

Fig. 32-33

Arbustos 1,5 m. Ramos cilíndricos, glabros. Pecíolo semicilíndrico, 3-5 mm, glabro, lâmina elípticolanceolada, $6-9 \times 2-3,5 \mathrm{~cm}$, puberulenta sobre as nervuras na superfície dorsal, nervura primária proeminente em ambas as superfícies, ápice agudo, base atenuada; estípulas caducas, bipartidas, lobos lanceolados, margens ciliadas. Inflorescências em cimeiras corimbiformes, terminais, multifloras, pedúnculos 2-4 cm; brácteas lanceoladas; flores sésseis, 5-meras, distílicas; cálice $2 \mathrm{~mm}$, subdenticulado, dentes triangulares, ciliados; corola campanulada, branca, 5-8,5 mm, externamente glabra, internamente com anel de tricomas na região de inserção dos estames, lobos lanceolados, 1,5-2 mm, ápice fendido; estames inclusos ou exsertos; filetes $0,5-1 \mathrm{~mm}$; anteras lanceoladas; estilete incluso ou exserto, 3,5-8 mm; estigma bífido. Fruto drupáceo, subgloboso, levemente sulcado, 3-5×1-3 mm, preto na maturidade; sementes plano-convexas, castanho-escuras, superfície ventral plana com sulco longitudinal, superfície dorsal 5-costada.

Material examinado: BRASIL. Minas Gerais: Viçosa, RFMP, trilha principal, 6/XI/2001, fl., Pereira \& Valente 39 (VIC); trilha lateral, 17/I/2002, fr., Pereira et al. 51 (VIC).

Segundo Andersson (1992), Psychotria conjugens distribui-se desde o sul do Pará até o Rio Grande do Sul. Na RFMP, está representada por vários indivíduos, distribuídos no interior da mata. Floresceu de novembro a janeiro e frutificou de janeiro a agosto. No campo, pode ser reconhecida, mesmo vegetativamente, pela coloração verde-amareladas das folhas jovens e estípulas bipartidas com lobos lanceolados.

22. Psychotria hastisepala Müll. Arg., Fl. Bras. 6(5): 350. 1881.

Fig. 34-35

Arbustos 1,5 m. Ramos cilíndricos, glabros. Pecíolo semicilíndrico, 1,1-1,2 cm; lâmina elíptico-lanceolada, coriácea, 7-11×3-4,5 cm, glabra, nervuras primária e secundárias proeminentes em ambas as superfícies, ápice agudo, base atenuada; estípulas caducas, bipartidas, glabras, lobos lanceolados. Inflorescências sésseis, em glomérulos, terminais; brácteas e bractéolas involucrais, paleáceas, persistentes; flores sésseis, 5-meras, distílicas; cálice $5 \mathrm{~mm}$, lobos 3-4 mm, hastiformes, paleáceos; corola infundibuliforme, branca, 10-15,5 mm, lobos triangulares 1,5-3 mm, externamente glabra, internamente com anel de tricomas na metade superior do tubo; estames inclusos ou exsertos; filetes 1-4 mm; anteras lanceoladas; estilete, incluso ou exserto, 8-13 mm; estigma bífido. Fruto drupáceo, obovóide, 2-1,2 cm, azul a violáceo na maturidade; sementes plano-convexas, castanho-claras, superfície ventral plana com sulco longitudinal, superfície dorsal lisa.

Material examinado: BRASIL. Minas Gerais: Viçosa, RFMP, trilha principal, 17/I/2002, fl., Pereira et al. 49 (VIC); trilha principal, 28/III/2002, fr., Pereira et al. 78 (VIC).

Psychotria hastisepala distribui-se desde o sul do Pará até o Rio Grande do Sul (Andersson 1992). Na RFMP está representada por vários indivíduos distribuídos no interior da mata. Floresceu de janeiro a março e frutificou de abril a junho. Caracteriza-se por suas folhas coriáceas, glomérulos sésseis, terminais com muitas brácteas e bractéolas involucrais que permanecem nos indivíduos após a floração.

23. Psychotria hygrophiloides Benth., Linnaea 23: 455. 1850.

Fig. 36

Ervas perenes, eretas, $40 \mathrm{~cm}$. Ramos cilíndricos, glabros. Pecíolo semicilíndrico, 3-5 mm, seríceo; lâmina lanceolada, 5-8 $\times 1-2 \mathrm{~cm}$, serícea, principalmente sobre as nervuras em ambas as superfícies, nervura primária proeminente em ambas as superfícies, ápice cuspidado, base atenuada; estípulas caducas, bipartidas, seríceas, lobos lanceolados. Inflorescências em glomérulos, terminais, pedúnculos $1,2 \mathrm{~cm}$; brácteas foliáceas; flores sésseis, 5-meras, distílicas; cálice 1,5 mm, lobos triangulares reduzidos, seríceos; corola tubulosa, 6-7 mm, branca, externamente sericea, internamente com anel de tricomas no local de inserção dos estames, 

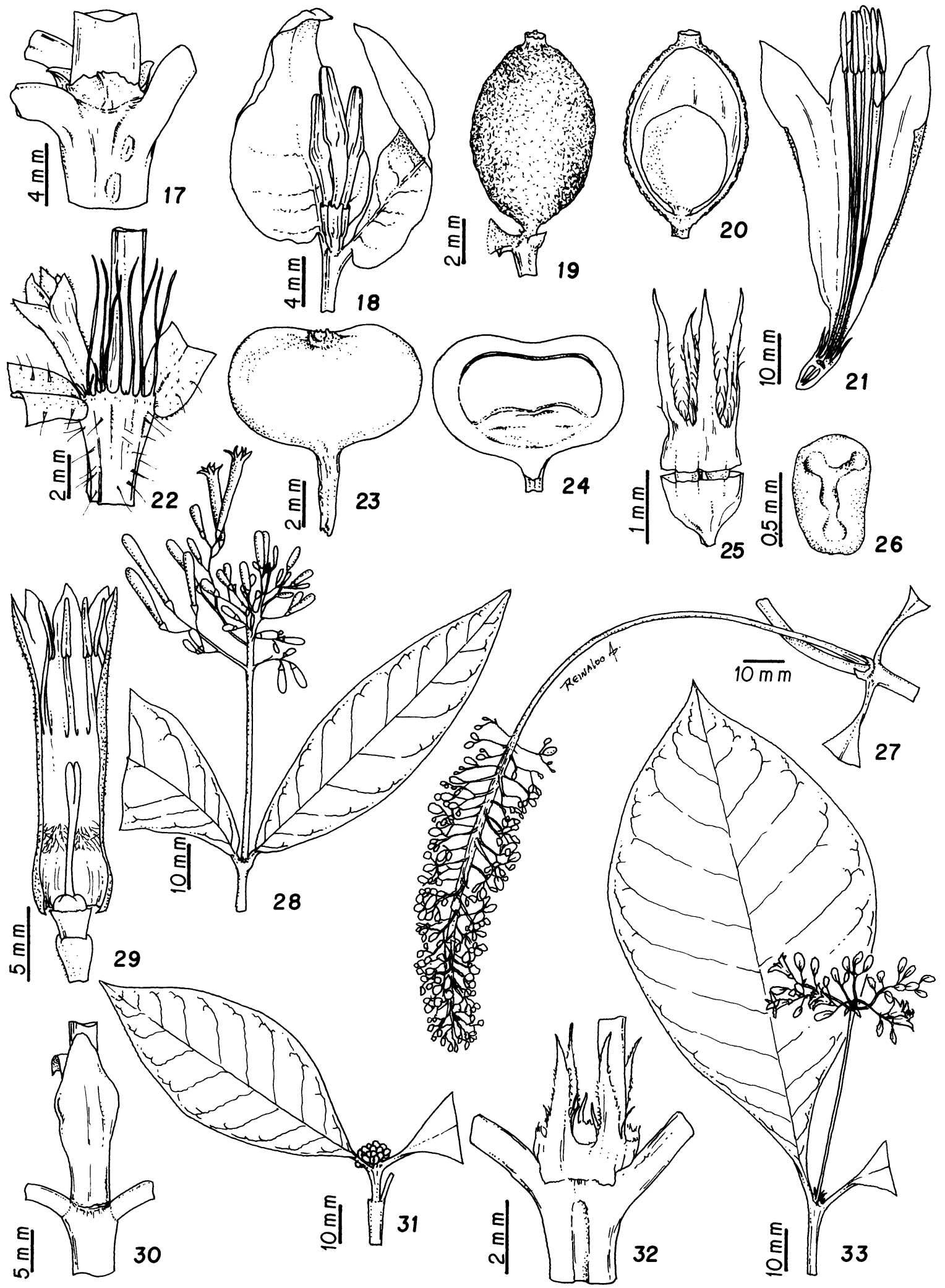

Figuras 17-33. Coussarea verticillata (Pereira \& Basílio 60). 17. Estípulas. 18-20. Coussarea triflora (Pereira \& Valente 89). 18. Inflorescência. 19. Fruto. 20. Fruto seccionado. 21. Coutarea hexandra (Pereira \& Basílio 65), flor. 22. Diodia teres (Pereira \& Basílio 69), inflorescência e estípulas. 23-24. Faramea multiflora (Pereira \& Basílio 62). 23. Fruto. 24. Fruto seccionado. 25-26. Mitracarpus frigidus (Pereira et al. 7). 25. Fruto. 26. Semente. 27. Palicourea longepedunculata (Pereira \& Basílio 61), inflorescência. 28-29. Palicourea marcgravii (Pereira et al. 47). 28. Inflorescência. 29. Flor. 30. Psychotria carthagenensis (Pereira \& Valente 87), estípulas. 31. Psychotria cephalantha (Pereira et al. 53), inflorescência. 32-33. Psychotria conjugens (Pereira \& Valente 39). 32. Estípulas. 33. Inflorescência. 
lobos lanceolados, 1,8-2 mm, ápices recurvados; estames inclusos ou exsertos; filetes $2 \mathrm{~mm}$; anteras lanceoladas; estilete incluso ou exserto, $4 \mathrm{~mm}$; estigma bífido. Fruto não observado.

Material examinado: BRASIL. Minas Gerais: Viçosa, RFMP, trilha principal, 6/XI/2001, fl., Pereira et Valente 38 (VIC).

Psychotria hygrophiloides ocorre desde o Ceará até o Rio Grande do Sul (Andersson 1992). Na RFMP, está representada por uma única população localizada na trilha principal. Floresceu de outubro a dezembro e não frutificou. Dentre as espécies de Psychotria amostradas, é a única que apresenta o porte herbáceo.

24. Psychotria myriantha Müll. Arg., Flora 59: 549, 552.1876.

Fig. 37

Arbustos 2,5 m. Ramos cilíndricos, glabros. Pecíolo semicilíndrico, 1-2 cm, glabro; lâmina elípticolanceolada, 7-18×4-8 cm, glabra, nervuras primária e secundárias proeminentes em ambas as superfícies, ápice acuminado, base atenuada; estípulas persistentes, inteiras, 4-aristada. Inflorescências em cimeiras paniculiformes, terminais, pedúnculos 1,5-3 cm; brácteas triangulares, lanceoladas, $2 \mathrm{~mm}$; flores subsésseis, 5-meras, distílicas, pedicelos $1 \mathrm{~mm}$; cálice 0,5-1 mm, glabro, lobos lanceolados; corola tubulosa, branca, 2-4 mm, externamente glabra, internamente com longos tricomas na região de inserção dos estames, lobos triangulares, 1-1,5 mm, reflexos, com ápices recurvados; estames inclusos ou exsertos, filetes $0,5-1 \mathrm{~mm}$; anteras elipsóides; estilete incluso ou exserto, 1-3,5 mm; estigma bífido, Fruto drupáceo, globoso, liso, 4-5×5,5-7 mm, preto na maturidade; sementes plano-convexas, castanhoescuras, superfície ventral com profundo sulco longitudinal, superfície dorsal 5-costada.

Material examinado: BRASIL. Minas Gerais: Viçosa, RFMP, trilha lateral, 6/XI/2001, fl., fr. Pereira \& Valente 40 (VIC).

Psychotria myriantha ocorre no Amazonas (Andersson 1992) e de Minas Gerais até o Rio Grande do Sul (Smith \& Downs 1956; Porto et al. 1977). Na RFMP, está representada por muitos indivíduos, todos ocorrendo no interior da mata, principalmente em locais mais úmidos e sombreados. Floresceu de novembro a janeiro e frutificou de dezembro a agosto.

25. Psychotria nuda (Cham. \& Schltdl.) Wawra, Itin. Princ. Coburg. 1: 128. 1883.

Fig. 38-39
Arbustos 2,5 m. Ramos cilíndricos, glabros. Folhas subsésseis, pecíolo semicilíndrico, 1-1,5 mm; lâmina elíptica, $5-7 \times 2-4 \mathrm{~cm}$, glabra na superfície ventral, hirsuta sobre a nervura primária na superfície dorsal, nervuras primária e secundárias pouco proeminentes na superfície dorsal, ápice curtamente cuspidado, base atenuada; estípulas glabras, persistentes, bipartidas, lobos triangulares. Inflorescências sésseis, triflora, terminais; 3 brácteas sepalóides; flores sésseis, 5-meras, distílicas; cálice campanulado, 1,5-2 cm, vermelho, glabro, lobos obtusos; corola infundibuliforme, 1,8-2,5 cm, amarela, carnosa, externamente glabra, internamente com anel de tricomas na metade superior do tubo, lobos lanceolados, 4-6 mm; estames inclusos ou exsertos; filetes 2-4 $\mathrm{mm}$; anteras lanceoladas; estilete incluso ou exserto, 0,8-2 cm; estigma bífido. Fruto drupáceo, elipsóide, 1-1,5×0,8-1 cm, azul a violáceo; sementes plano-convexas, castanho- claras, superfície ventral plana, com sulco longitudinal, superfície dorsal com uma única costela.

Material examinado: BRASIL. Minas Gerais: Viçosa, RFMP, trilha principal, 17/I/2002, fl., Pereira, et al. 55 (VIC); trilha principal, 26/II/2001, fr., Pereira \& Basílio 58 (VIC).

Psychotria nuda distribui-se desde a Bahia até o Rio Grande do Sul (Andersson 1992). Na RFMP, está representada por poucos indivíduos, todos encontrados na parte mais úmida da mata. Floresceu de janeiro a maio e frutificou de fevereiro a junho. Dentre as espécies de Psychotria amostradas na RFMP, é a única que apresenta inflorescência triflora com brácteas sepalóides, cálice vermelho, corola carnosa, amarela.

26. Psychotria sessilis Vell., Fl. Flumin 1: 65. 2: t. 26. 1825.

Fig. 40-41

Arbustos $3 \mathrm{~m}$. Ramos cilíndricos, puberulentos. Pecíolo semicilíndrico, 5-7 mm, glabro, lâmina lanceolada, 4-7×1-1,5 cm, glabra, brilhante, nervura primária proeminente em ambas as superfícies, nervuras secundárias com 20 ou mais pares, paralelas, perpendiculares à nervura primária, ápice cuspidado, base atenuada; estípulas caducas, glabras, bipartidas. Inflorescências curto-pedunculadas, em glomérulos, axilares, pedúnculos 3-5 $\mathrm{mm}$; brácteas triangulares, $4 \mathrm{~mm}$; flores sésseis, 5-meras, distílicas; cálice $1 \mathrm{~mm}$, lobos triangulares, ciliados; corola infundibuliforme, branca, 7-8,5 $\mathrm{mm}$, externamente glabra, internamente com anel de tricomas na região de inserção dos 
estames, lobos triangulares, 3-4 mm, ápices recurvados; estames inclusos ou exsertos, filetes 0,5-5 $\mathrm{mm}$; anteras lanceoladas; estilete incluso ou exserto, 3-8 mm, estigma bífido. Fruto drupáceo, levemente comprimido, 4-6×2-3 mm, azul escuro na maturidade; sementes plano-convexas, castanhoescuras, superfície ventral plana com sulco longitudinal, superfície dorsal 5-costada.

Material examinado: BRASIL. Minas Gerais: Viçosa, RFMP, trilha principal, 2/XI/2001, fl., Pereira \& Rossi 14 (VIC); trilha principal, 26/II/2001, fr., Pereira \& Basílio 58 (VIC).

Psychotria sessilis distribui-se na Venezuela, Trinidad e Tobago, Guiana, Suriname, Guiana Francesa, Brasil e Paraguai (Andersson 1992). No Brasil, é encontrada do Amazonas até o Rio Grande do Sul (Andersson 1992). Na RFMP, é a mais abundante, sendo observada em toda a mata. Floresceu de outubro a dezembro e frutificou de janeiro a agosto.

27. Psychotria subspathulata (Müll. Arg.) C.M. Taylor, Novon 9(2): 261. 1999.

Fig. $42-44$

Arbustos 1,5 m. Ramos cilíndricos, glabros. Pecíolo semicilíndrico, 3-5 mm, puberulento; lâmina lanceolada, 5-7,5 $\times 0,5-1 \mathrm{~cm}$, puberulenta, sobre a nervura primária na superfície dorsal, nervuras primária e secundárias proeminentes na superfície dorsal, nervuras secundárias com até 8 pares, oblíquas a nervura primária, ápice subacuminado, base atenuada, margem ondulada; estípulas caducas, inteiras, reflexas, lanceoladas, externa e internamente pilosas. Inflorescências curtopedunculadas, em cimeiras corimbiformes, terminais, pedúnculos puberulentos, 4-5 $\mathrm{mm}$; brácteas triangulares; flores sésseis, 5-meras, distílicas; cálice $2 \mathrm{~mm}$, lobos triangulares, muito reduzidos, ciliados; corola tubulosa, branca, 2,5-4 mm, externamente puberulenta, internamente com anel de tricomas no local de inserção dos estames, lobos oval-lanceolados, 1,5-2 mm, reflexos na flor em antese, ápices recurvados; estames inclusos ou exsertos; filetes $0,5-1,5 \mathrm{~mm}$; anteras elipsóides; estilete incluso ou exserto 1-2,5 mm; estigma bífido. Fruto drupáceo, elipsóide, multisulcado, 5-7× 3-4 mm; sementes plano-convexas, castanho-escuras, superfície ventral plana com vários sulcos longitudinais, superfície dorsal 4-costada.

Material examinado: BRASIL. Minas Gerais: Viçosa, RFMP, trilha principal, 8/XII/2001, fl., Pereira \& Lobtchenko 45 (VIC); Astolfo Dutra, 7/IV/1998, fr., Salino 4178 (BHCB).
Psychotria subspathulata distribui-se desde a Bahia até o Rio Grande do Sul (Andersson 1992). Na RFMP, foram encontrados poucos indivíduos no interior da mata. Floresceu de novembro a dezembro e frutificou de janeiro a maio. Dentre as espécies de folhas estreitas (comprimento/largura >3/1), $P$. subspathulata é a única que apresenta lâmina foliar ondulada e nervuras secundárias (8 pares), oblíquas à primária.

28. Psychotria vellosiana Benth., Linnaea 23: 464. 1850.

Fig. 45-46

Arbustos 3 m. Ramos cilíndricos, velutinos. Pecíolo semicilíndrico, velutino, 2-3 mm; lâmina lanceolada, 5-7×1-1,5 cm, velutina, nervuras secundárias com 20 ou mais pares, paralelas, perpendiculares à nervura primária, ápice agudo, base obtusa; estípulas caducas, inteiras, concrescidas, lanceoladas, 4-aristada, velutinas. Inflorescências sésseis, em glomérulos axilares; muitas brácteas involucrais, velutinas; flores sésseis, 5-meras, distílicas; cálice truncado, $1 \mathrm{~mm}$, velutino; corola tubulosa, branca, 5-7 mm, externamente velutina, internamente com anel de tricomas no local de inserção dos estames, lobos lanceolados, 1,5-2 mm, parcialmente reflexos, ápices recurvados; estames inclusos ou exsertos; filetes 1-2,5 mm; anteras lanceoladas; estilete incluso ou exserto, 2,5-4 mm, estigma bífido. Fruto drupáceo, elipsóide, liso, 4-5×2-3 mm, preto na maturidade; sementes plano-convexas, castanho escuras, superfície ventral plana com um sulco longitudinal, superfície dorsal 4-costada.

Material examinado: BRASIL. Minas Gerais: Viçosa, RFMP, trilha principal. 3/VII/2001, fr., Pereira et al. 06 (VIC); 2/VIII/2002, fr., Pereira et al. 91 (VIC).

Segundo Andersson (1992), esta espécie distribuise pela Venezuela, Brasil e Paraguai. No Brasil, ocorre desde Pernambuco até Santa Catarina. Na RFMP, está representada por muitos indivíduos, todos no interior da mata. Floresceu de outubro a janeiro e frutificou de fevereiro a agosto.

29. Richardia grandiflora (Cham. \& Schltdl.) Steud., Nomench. Bot. (ed. 2) 2: 459. 1841.

Fig. 48-49

Ervas anuais, prostradas, ca. $40 \mathrm{~cm}$. Ramos semicilíndricos, hirsutos. Folhas subsésseis, lâmina elíptico-lanceolada, 2-4,5×0,5-1 cm, hirsuta, nervura primária proeminente na superfície dorsal, nervuras secundárias inconspícuas, ápice agudo, base atenuada; 


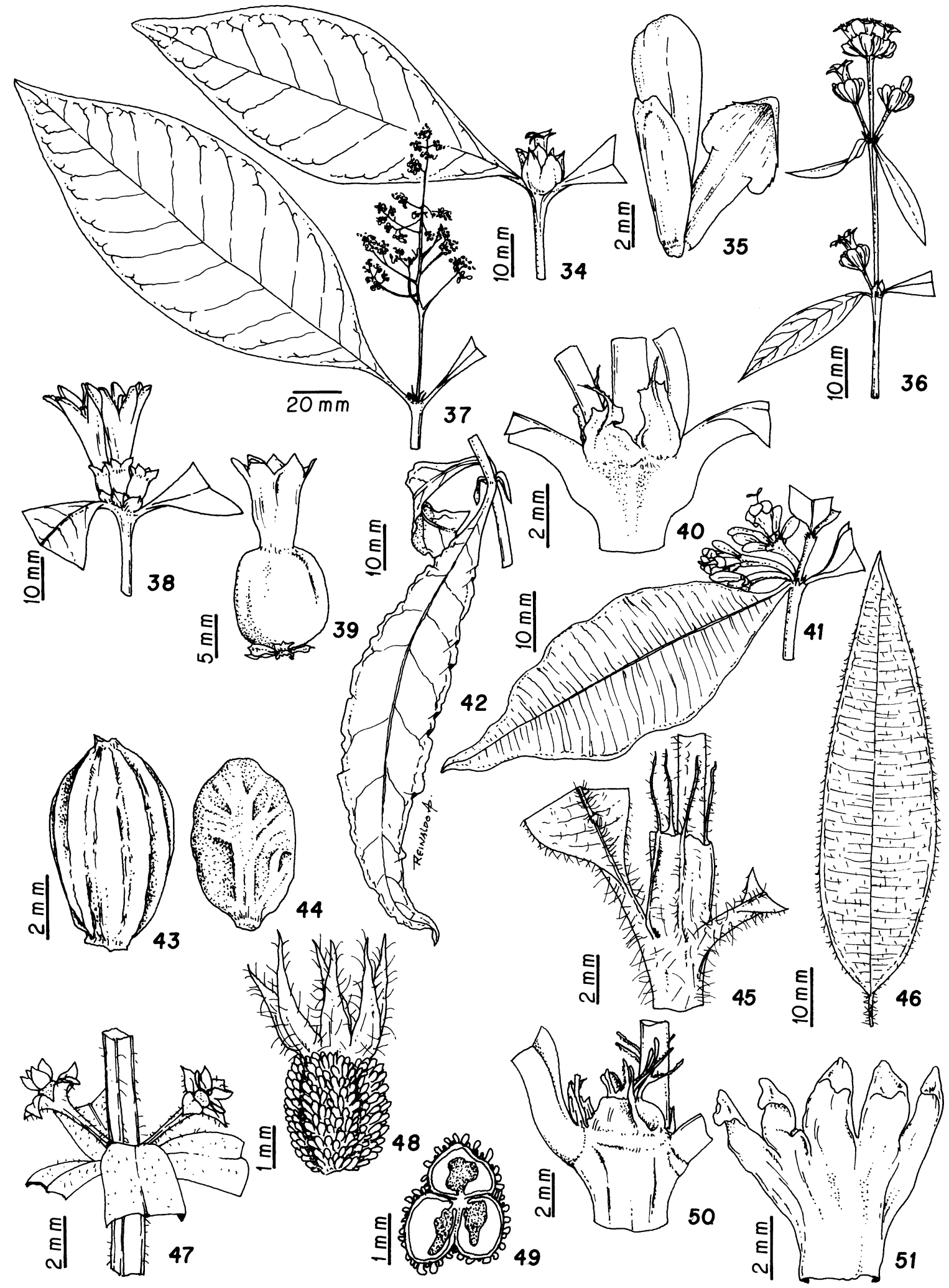

Figuras 34-51. Psychotria hastisepala (Pereira et al. 48): 34. Inflorescência. 35. Botão floral. Psychotria hygrophiloides (Pereira \& Valente 38): 36. Ramo fértil. Psychotria myriantha (Pereira \& Valente 40). 37. Inflorescência e folha. Psychotria nuda (Pereira et al. 55): 38. Inflorescência. 39. Fruto. Psychotria sessilis (Pereira \& Rossi 14): 40. Estípulas. 41. Folha e inflorescência. Psychotria subspathulata (Pereira \& Lobtchenko 45): 42. Folha. 43. Fruto. 44. Semente. Psychotria vellosiana (Pereira et al. 10): 45. Estípulas. 46. Folha. Galium hypocarpium (Pereira et al. 56): 47. Estípulas e flores. Richardia grandiflora (Pereira \& Valente 57): 48. Fruto. 49. Fruto seccionado. Rudgea lanceolata (Pereira \& Basílio 59): 50. Estípulas. 51. Corola. 
estípulas 5-cerdosas. Inflorescências em glomérulos terminais, multifloros; 4 brácteas foliáceas, ovais, hirsutas, as superiores com $0,5-1 \times 0,5 \mathrm{~cm}$ e as inferiores 1-2,5×1 cm; flores sésseis, 6-mera; cálice $3,5 \mathrm{~mm}$, lobos lanceolados, $3 \mathrm{~mm}$, pilosos; corola tubulosa, branca, 12-20 mm, externamente pilosa, lobos triangulares, $6 \mathrm{~mm}$, róseos, ciliados; estames exsertos; filetes $1 \mathrm{~mm}$; anteras elipsóides; ovário tricarpelar, trilocular; estilete exserto, $1 \mathrm{~cm}$, estigma discóide. Fruto esquizocarpo com 3 mericarpos indeiscentes, obovóide, muricado, 1,8-2,7×1 mm; sementes obovadas, planoconvexas, castanhas levemente brilhantes, superfície dorsal lisa e superfície ventral com sulco longitudinal.

Material examinado: BRASIL. Minas Gerais: Viçosa, RFMP, trilha principal,19/II/2002, fl., fr., Pereira et Valente 57 (VIC).

Richardia grandiflora distribui-se na Bolívia, Brasil, Paraguai e Argentina. No Brasil, ocorre desde o Maranhão até o Rio Grande do Sul (Lewis \& Oliver 1974). Na RFMP, foi encontrada uma única população distribuída na trilha principal. Floresceu e frutificou de setembro a junho. Caracteriza-se pelo porte herbáceo, prostrado, densamente piloso, folhas subsésseis, estípulas 5-cerdosas, que se confundem com a grande quantidade de pêlos, inflorescências em glomérulos terminais, multifloros, brácteas foliáceas ovais, flores hexâmeras e frutos esquizocarpos com mericarpos muricados.

30. Rudgea lanceolata (Schltdl. \& Cham.) Benth., Linnaea 23: 455. 1850.

Fig. 50-51

Arbustos 3,5 m. Ramos cilíndricos, glabros. Pecíolo semicilíndrico, 5-7 mm, glabro; lâmina lanceolada, 8-11×2,5-4 mm, glabra, nervura primária proeminente na superfície dorsal, ápice cuspidado, base obtusa; estípulas inteiras, triangulares, com segmentos subulados agrupados no ápice. Inflorescências sésseis, em cimeiras glomeriformes, terminais; brácteas triangulares; flores sésseis, 5-meras; cálice $3 \mathrm{~mm}$, lobos lanceolados, 1,5 mm, ciliados; corola infundibuliforme, branca 7,5-11,5 mm, externamente glabra, internamente com anel de tricomas no local de inserção dos estames, lobos triangulares, $2-3 \mathrm{~mm}$, corniculados, estames inclusos ou exsertos; filetes 1-1,5 mm; anteras elipsóides; estilete incluso ou exserto, 5-11,5 mm; estigma bífido. Fruto drupáceo, obovado, ápice aplanado, liso, 7-5×3-4 mm; sementes plano-convexas, castanho-escuras, superfície dorsal lisa, superfície ventral com sulco transversalmente ampliado.

Material examinado: BRASIL. Minas Gerais:
Viçosa, RFMP, trilha lateral, 26/II/2002, fr., Pereira \& Basílio 59 (VIC); Viçosa, X/1994, fl., Meira Neto 2164 (VIC).

Rudgea lanceolata distribui-se desde o Pará até Rio Grande do Sul (Andersson 1992). Na RFMP, está representada por vários indivíduos, distribuídos no interior da mata. Floresceu de novembro a janeiro e frutificou de janeiro a abril. No local de estudo, é a única que apresenta estípulas triangulares com segmentos subulados e corola com lobos corniculados.

\section{Agradecimentos}

À coordenação de Aperfeiçoamento de Pessoal de Nível Superior (CAPES), pela bolsa concedida à primeira autora; ao Reinaldo A. Pinto, pelas ilustrações; aos funcionários do VIC, pelo auxílio e presteza; aos curadores dos herbários visitados; às professoras Milene Faria Vieira e Luíza Sumiko Kinoshita pela leitura crítica do manuscrito e valiosas sugestões.

\section{Referências bibliográficas}

Andersson, L.A. 1992. A Provisional checklist of Neotropical Rubiaceae. Scripta Botanica Bélgica 1: 1-199.

Bacigalupo, N.M. 1968. Revisón de las espécies del gênero Richardia (Rubiaceae) em la flora Argentina. Darwiniana 14(4): 639-53.

Bacigalupo, N.M. \& Cabral, E.L. 1996. Infrageneric classification of Borreria (Rubiaceae-Spermacoceae) on the basis of Americam species. Opera Botanica Belgica 7: 297-308.

Bacigalupo, N.M. \& Cabral, E.L. 1999. Revisón de las especies Americanas del gênero Diodia (RubiaceaeSpermacoceae). Darwiniana 37(1/2): 153-165.

Barroso, G.M.; Peixoto, A.L.; Costa, C.G.; Ichaso, C.L.F.; Guimarães, F. \& Lima, H.C. 1991. Sistemática de angiospermas do Brasil. 3 ed. Viçosa, MG, Universidade Federal de Viçosa.

Burger, W. \& Taylor, C.M. 1993. Rubiaceae: Flora Costaricensis. Field Museum of Natural History 33: 1-333.

Cabral, E.L. \& Bacigalupo, N.M. 1999. Estudio de las especies americanas de Borreria series Laeves (RubiaceaeSpermacoceae). Darwiniana 37(3/4): 259-277.

Costa, C.B. \& Mamede, M.C.H. 2002. Sinopse do gênero Coccocypselum P. Browne (Rubiaceae) no estado de São Paulo, Brasil. Biota Neotropica 2(1): 1-14.

Dempster, L.T. 1981. The genus Galium (Rubiaceae) in South America II. Allerlonia 2(8): 393-426.

Dempster, L.T. 1982. The genus Galium (Rubiaceae) in South America III. Allerlonia 3(3): 211-258.

Dempster, L.T. 1990. The genus Galium (Rubiaceae) in South America IV. Allerlonia 5(3): 283-345. 
Dillenburg, V.R. \& Porto, M.L. 1985. Rubiaceae, Tribo Psychotrieae. In: A.R.H. Schultz \& L.R.M. Baptista, (eds.). Flora ilustrada do Rio Grande do Sul. Boletim do Instituto de Biociências 39(16): 1-76.

Dimitri, S.B. 1959. Rubiaceae da cidade do Rio de Janeiro: tribo Spermacoceae. Rodriguésia 22(33/34): 241-283.

Dwyer, J.D. 1980. Rubiaceae. In: E.R. Woodson \& W.R. Schery (eds.). Flora of Panama. Annals of the Missouri Botanical Garden 67: 227-522.

Germano Filho, P. 1999. Estudos taxonômicos do gênero Bathysa C. Presl (Rubiaceae, Rondeletieae), no Brasil. Rodriguésia 50(76/77): 49-75.

Gomes, M. 1996. Rubiaceae. Pp. 345-426. In: M.P.M. Lima \& R.R. Guedes-Bruni (eds.). Reserva Ecológica de Macaé de Cima, Nova Frigurgo, RJ. Aspectos Florísticos das Espécies Vasculares. v.2, Rio de Janeiro, Jardim Botânico do Rio de Janeiro.

Gomes, M. 2003. Reavaliação taxonômica de algumas espécies dos gêneros Coussarea Aubl. e Faramea Aubl. (Rubiaceae, tribo Coussareae). Acta Botanica Brasilica 17(3): 449-466.

Holmgren, P.K.; Holmgren, N.H. \& Barnett, L.C.E.K. 1990. Index herbariorum Pl: the herbaria of theworld (Regnum Vegetabile V. 120). New York, New York Botanical Garden, 693p.

Judd, W.S.; Campbell, C.S.; Kellogg, E.A. \& Stevens, P.f. 1999. Plant systematics a phylogenetic approach. Massachusetts, USA, Sinauer Associates, Inc.

Jung-Mendaçolli, S.L. 1994. Flora fanerogâmica da Reserva do Parque Estadual das Fontes do Ipiranga (São Paulo, Brasil). Hoehnea 21( 1/2 ): 97-129.

Jung-Mendacolli, S.L. 1999. Rubiaceae. Pp. 160-166. In: M.M.R.F. Melo; F. Barros; S.A.C. Chiea; M. Kerezawa; S.L. Jung-Mendoçalli \& M.G.L. Wanderley (eds.). Flora Fanerogâmica da Ilha do Cardoso. v.3., São Paulo, Instituto de Botânica.

Kissmann, K.G. \& Groth, D. 2000. Plantas infestantes e nocivas. 2 ed., v.3, São Paulo, BASF.

Krause, K. \& Hoehne, F.C. 1922. Conhecimento das Rubiaceae do Brasil Meridional. Memórias do Instituto de Butantan 1(3): 1-33.
Lewis, W.H. \& Oliver, R.L. 1974. Revision of Richardia (Rubiaceae). Brittonia 26: 271-301.

Lorenzi, H. 1998. Árvores Brasileiras: manual de identificação e cultivo de plantas arbóreas nativas do Brasil. v. 2., Nova Odessa, SP, Plantarum.

Miotto, S.T.S. 1975. Revisão preliminar do gênero Borreria G.F.W. Meyer (Rubiaceae) no estado do Rio Grande do Sul. Iheringia 20(1): 17-25.

Müller, J. 1881. Rubiaceae I. In: C.F.P. von Martius; A.W. Eichler \& I. Urban. Flora Brasiliensis..., Leipzig, München, 6(5): 1-486.

Porto, M.L.; Jaques, S.M.C.; Miotto, S.T.S.; Waechter, J.L. \& Detoni, M.L. 1977. Tribo Spermacoceae. Rubiaceae. In: A.R.H. Schultz \& M.H. Honrich (eds.). Flora ilustrada do Rio Grande do Sul. Boletim do Instituto de Biociências 35(12): 1-114.

Rambo, B.S.J. 1962. Rubiaceae Riograndenses. Sellowia 18: $1-75$.

Rizzini, C.T. 1992. Tratado de fitogeografia do Brasil: aspectos ecológicos, sociológicos e florísticos. São Paulo, Âmbito Cultural.

Robbrecht, E. 1988. Tropical woody Rubiaceae. Opera Botanica Belgica 1: 1-127.

Schumann, K 1889. Rubiaceae I. In: C.F.P. von Martius; A.W. Eichler \& I. Urban. Flora Brasiliensis..., Leipzig, München, 6(6): 1-466.

Smith, L.B. \& Downs, R.J. 1956. Resumo preliminar das Rubiaceae de Santa Catarina. Sellowia 7: 13-86.

Steyermark, J.A. 1967. Rubiaceae. In: B. Maguire \& J.J. Wurdack (eds.). Botany of the guayana Highlands, Part VII. Memoirs of New York Botanical Garden 17(1): 230-436.

Steyermark. J.A. 1974. Rubiaceae. In: T. Lasser (ed.). Flora da Venezuela. Caracas, Venezuela, Instituto Botanico, Dirección de Recursos Naturales Renoables, Ministério de Agricultura Y Cría.

Veloso, H.P.; Rangel Filho, A.R. \& Lima, J.C.A. 1991. Classificação da vegetação brasileira, adaptada a um sistema universal. Rio de Janeiro, IBGE.

Vianello, R.L. \& Alvez, A.R. 1991. Meteorologia básica e aplicações. Viçosa, Universidade Federal de Viçosa. 